P. Schempp*, R. Häcker*, A. Pittner*, C.E. Cross ${ }^{* *}$ i M. Rethmeier ${ }^{* * *}$

IIW Commission IX-NF (Non ferrous metals), IIW-Doc. IX-2401-12

\title{
INFLUENCE OF GRAIN SIZE ON MECHANICAL PROPERTIES OF
} ALUMINIUM GTA WELD METAL

\section{UTICAJ VELIČINE ZRNA NA MEHANIČKE OSOBINE METALA ŠAVA ALUMINIJUMA ZAVARENOG TIG POSTUPKOM}

\author{
Originalni naučni rad / Original scientific paper \\ UDK / UDC: Weld World (2014) 58:491-497; \\ DOI 10.1007/s40194-014-0132-0 \\ Rad primljen / Paper received: \\ Jul 2015.
}

Prevod izvornog rada na srpski jezik: Milica Antić,dipl.ing

Key words: GTA welding; Aluminium; Grain refinement; Tensile tests; Tear tests.

\begin{abstract}
Grain refinement is an important possibility to enhance the mechanical properties such as strength, ductility and toughness of aluminium weld metal. In this study, grain refinement was achieved through the addition of commercial grain refiner $\mathrm{Al}$ Ti5B1 to GTA (gas tungsten arc) weld metal of the aluminium alloys 1050A (Al 99,5) and 5083 (Al $\mathrm{Mg} 4,5 \mathrm{Mn0}, 7)$. The grain refiner additions led to a significant reduction of the weld metal mean grain size (Alloy 1050A: 86\%, Alloy 5083: 44\%) with a change in grain shape from columnar to equiaxed. In hardness tests, no relationship between hardness and weld metal mean grain size was found. Tensile tests showed for Alloy 5083 that the weld metal's ductility can be increased through grain refinement. No improvement in weld metal strength (i.e. yield strength and ultimate tensile strength) was observed. Furthermore, tear tests with notched specimens revealed that the resistance against initiation and propagation of cracks in the weld metal can be enhanced through grain refinement. This increase in toughness was found to depend strongly on the alloying composition and hence on size, distribution and chemical composition of the intermetallic phases. Accordingly, the toughness was observed to increase clearly by grain refinement in weld metal of commercially pure Al (Alloy 1050A). In Alloy 5083 weld metal, the toughness was not improved through grain refinement, likely because of a semicontinuous network of brittle intermetallic phases that facilitate crack propagation.
\end{abstract}

\begin{abstract}
Adresa autora / Author's address:
${ }^{*}$ Dipl.-Ing. Philipp SCHEMPP (Philipp.Schempp@bam.de), *Dipl.-Ing. Ralf HÄCKER (Ralf.Haecker@bam.de),

*Dr.-Ing. Andreas PITTNER (Andreas.Pittner@bam.de) BAM Federal Institute for Materials Research and Testing,Berlin (Germany). Prof.

**Dr. Carl Edward CROSS (CECross@lanl.gov) is with LANL Los Alamos National Laboratory, Los Alamos (USA).

${ }^{* * *}$ Dr.-Ing. Michael RETHMEIER (Michael.Rethmeier@bam.de) and IPK - Fraunhofer Institute for Production Systems and Design Technology, Berlin (Germany).
\end{abstract}

Ključne reči: TIG zavarivanje; Aluminijum; rafinacija zrna; Ispitivanje zatezanjem; Ispitivanje cepanjem

\section{Rezime}

Rafinacija zrna je važna mogućnost za promenu mehaničkih osobina kao što su čvrstoća, duktilnost i žilavost metala šava od aluminijuma. U ovoj studiji, rafinacija zrna je postignuta dodavanjem komercijalnog rafinatora zrna Al Ti5B1 TIG-om stvorenom metalu šava aluminijumskih legura 1050A (Al 99,5) i 5083 (Al Mg4,5Mn0,7). Dodaci rafinatora zrna dovode do značajnog smanjenja veličine zrna metala šava (legura 1050A: 86\%, legura 5083: 44\%) uz promenu oblika zrna od stubičastog do jednakoosnog. Pri ispitivanju tvrdoće, nije pronađen odnos između tvrdoće i veličine zrna u metalu šava. Ispitivanje zatezanjem je pokazalo da kod legure 5083, duktilnost metala šava može da poraste rafinacijom zrna. Povećanje čvrstoće metala šava (odn. napon tečenja i zatezna čvrstoća) nije zapaženo. Štaviše, ispitivanje cepanjem na epruvetama sa zarezom je otkrilo da otpornost na nastanak i širenje prslina u metalu šava, može biti izmenjena preko rafinacije zrna.

Za ovo povećanje žilavosti nađeno je da veoma zavisi od sastava legure i stoga od veličine, raspodele i hemijskog sastava intermetalnih faza. Prema tome, ustanovljeno je da žilavost jasno raste rafinacijom zrna u metalu šava kod komercijalno čistog metala Al (legura 1050A). Kod metala šava legure 5083, žilavost se ne povećava sa rafinacijom zrna, verovatno zbog polukontinualne mreže krtih intermetalnih faza koja olakšava širenje prslina. 


\section{Uvod i osnovne informacije}

Rafinacija zrna je vrlo značajan mehanizam ojačavanja metalnih materijala, pored ojačavanja čvrstim rastvorom, taložnog otvrdnjavanja i deformacionog ojačavanja. Prednost finozrne mikrostruktre je visok napon tečenja, t.j. velika otpornost na plastičnu deformaciju. Plastična deformacija se odnosi na kretanje defekata atomske rešetke (npr. dislokacije), što rezultuje u klizanju atoma po poželjnim ravnima kristala [1]. Otuda kretanje dislokacija treba da bude sprečeno da bi se postigao visok napon tečenja. Ovo se može postići mnoštvom malih i tvrdih taloga (precipitaciono otvrdnjavanje) ili granicama zrna (ojačavanje veličinom zrna): Manja zrna, veće oblasti sa granicama zrna, stvaraju barijere za prostiranje klizanja od jednog do drugog zrna [1]. Štaviše, dislokacije se odbijaju jedne od drugih tako da svaka dislokacija zahteva određenu količinu energije za početak kretanja, iz čega proizilazi da velika gustina dislokacija, takođe povećava napon tečenja. Ovaj deformacioni mehanizam se primenjuje kod obrade metala na hladno. Dodatno, velika gustina dislokacija omogućava veći stepen plastične deformacije i tada obezbeđuje narednu značajnu prednost: veliku duktilnost. Poznato je da povećanje gustine dislokacija takođe može da bude postignuto rafinacijom zrna tokom plastične deformacije (rafinacija zrna u čvrstom stanju) [1].

Postoji nekoliko objašnjenja za mehanizam ojačavanja preko veličine zrna: Hall [2] i Petch [3] su tvrdili da se dislokacije nagomilavaju na granicama zrna proizvodeći naprezanje, koje konačno dozvoljava da se plastična deformacija širi kroz susedno zrno. Veća veličina zrna, više je izražena ako se dislokacije nagomilavaju na svakoj granici zrna, veći je lokalni napon i manja je otpornost na tečenje. Cottrell [4] je predvideo da nagomilavanje dislokacija na granici zrna dovodi do stvaranja Frank-Read-ovih izvora koji stvaraju naredne dislokacije, što povećava gustinu dislokacija i usled toga čvrstoću. Li [5] je predvideo da se dislokacije ne nagomilavaju, ali se stvaraju u tankim ispupčenjima-ivicama na granicama zrna. Štaviše, širenje plastične deformacije između dva susedna zrna zahteva više energije ako je ugao između atomskih rešetki oba zrna, veliki. Ovo naglašava potrebu za mnoštvom različito orijentisanih zrna i tako za finozrnom strukturom [6]. Posledica toga je da granice zrna blokiraju širenje dislokacija / plastičnu deformaciju sa jedne strane, što povećava čvrstoću. S druge strane, granice zrna mogu da povećaju gustinu dislokacija nastajanjem novih dislokacija, što povećava duktilnost. Povećanje napona tečenja ojačavanjem preko veličine zrna, može se opisati Hall-Petchovom jednačinom koja glasi

$$
\sigma=\sigma_{0}+k \cdot d^{-0,5}
$$

gde su $\sigma_{0}$ i $k$ parametri materijala na koje utiče sastav legure, oblik zrna i kristalogrfaska tekstura [7]. $\sigma_{0}$ je napon trenja koji je mali za čiste metale (10 MPa za čisti Al) i raste sa porastom sadržaja elemenata u leguri (npr. $20 \mathrm{MPa}$ za 99,5 tež.\% Al) zavisno od ojačavanja čvrstim rastvorom [8]. $k$ karakteriše teškoću prenosa klizanja duž granica zrna [9] i stoga predstavlja sposobnost ojačavanja preko veličine zrna za dati sistem legura. Ojačavanje preko veličine zrna, međutim, nije tako veliko kod aluminijuma, tako da je $k$ mali za većinu Al legura (2 N/mm $3 / 2$ do $6 \mathrm{~N} / \mathrm{mm}^{3 / 2}$ [9-11]) u poređenju sa $4 \mathrm{~N} / \mathrm{mm}^{3 / 2}$ za Cu [12], $10 \mathrm{~N} / \mathrm{mm}^{3 / 2}$ za mesing [12] i $22 \mathrm{~N} / \mathrm{mm}^{3 / 2}$ za nelegirani čelik [13]. Štaviše, što je veća plastična deformacija, to je niži je $k$; za $\mathrm{Al}, k$ može biti 0 pri deformaciji > $10 \%$ [8].

Sprovedene su mnoge studije o uticaju veličine zrna na mehaničke osobine Al legura. Napon tečenja Al-Mg legura može da se poveća do $25 \%$ rafinacijom zrana $[14,15]$. Duktilnost se jasno povećava ali ne i zatezna čvrstoća [16]. Hansen [8] je potvrdio da Hall-Petch-ova jednačina sa ispitivanjem zatezanjem za čisti Al, opoziva jednačinu (1). On je odredio preko TEM, gustinu dislokacija u hladno valjanim limovima od čistog Al (zavisnost od veličine zrna i deformacije) i potvrdio prethodne pristupe koji uzimaju u obzir to, da granice zrna proizvode dislokacije tokom deformacije. Prema tome, mikrostruktura sa malim veličinama zrna $(46 \mu \mathrm{m})$ proizvodi tri puta više dislokacija nego mikrostruktura sa velikim zrnima $(490 \mu \mathrm{m})$ (pri konstantnoj deformaciji = 10\%) [8]. Za 2xxx (Al-Cu), 5xxx (Al-Mg), 6xxx (Al-Mg-Si) i 7xxx (Al-Zn) legure, je utvrdio da postoje oprečni zahtevi za optimalni napon tečenja i optimalnu udarnu žilavost [17-19]: S jedne strane, veliki napon tečenja podrazumeva veliku otpornost na kretanje dislokacija. S druge strane, velika udarna žilavost podrazumeva visoku plastičnost i stoga potrebu za kretanjem dislokacija u cilju zaokruživanja prethodno postojećih prslina i otvrdnjavanja vrha prsline [18, 20]. Ipak, eksperimentalno je utvrđeno da rafinacija zrna može povećati udarnu žilavost. npr. legure 7075 [18]. 
Efekti rafinacije zrna na mehaničke osobine TIG zavarenih spojeva, ispitivani su na taložno otvrdnutim Al legurama u nekoliko studija. Ustanovljeno je da rafinacija zrna metala šava može da promeni posebno napon tečenja i duktilnost [21-23] i u nekim slučajevima zateznu čvrstoću metala šava [24]. U jednom slučaju, tvrdoća metala šava je poboljšana rafinacijom zrna [21]. Kod postupka "friction stir“, rafinacija zrna i intenzivna plastična deformacija mogu da rezultuju u vrlo visokim vrednostima čvrstoće, duktilnosti i žilavosti Al osnovnog materijala [25].

Pored poboljšanih mehaničkih osobina, sledeća značajna prednost finozrnog metala šava od aluminijuma, je smanjena osetljivost na solidifikacione prsline kod zavarivanja topljenjem [26-29], što može biti vezano za zavarljivost osnovnog materijala [30]. Veruje se da mala zrna sa istoosnim oblikom imaju veću otpornost na širenje solidifikacionih prslina zbog raspodele naprezanja između više granica zrna [31].

Rafinacija zrna metala šava može se postići kod elektrolučno zavarenih spojeva različitim metodama kao što su tehnike pulzirajuće struje [32] ili magnetnog mešanja zavarivačke kupke [33]. Međutim, najčešće korišćeni i najefektivniji pristup u zavarivanju aluminijuma je dodatak rafinatora zrna u metal šava [21, 28, 34]. Neke komercijalne žice za zavarivanje sadrže male količine elemenata rafinatora zrna koji se često koriste kod aluminijumskih odlivaka za rafinaciju njihove mikrostrukture. Tipična legura za rafinaciju zrna je npr. Al $\mathrm{Ti}_{5} \mathrm{~B}_{1}(\mathrm{Al}+5$ tež. $\% \mathrm{Ti}+1$ tež. $\%$ B) [35]. Titan i bor su prisutni u oblliku čestica kao što su $\mathrm{TiB}_{2}$ [36] i $\mathrm{Al}_{3} \mathrm{Ti}$ [37] koje deluju kao jezgra heterogenog očvršćavanja tokom očvršćavanja zavarivačke kupke. Stoga, dodaci rafinatora zrna dovode do povećanja čestica $\mathrm{TiB}_{2}$ i $\mathrm{Al}_{3} \mathrm{Ti}$ što finalno rezultuje u rafinaciji zrna [38]. Drugi zahtev za efektivnu rafinaciju zrna je dovoljan stepen podhlađivanja radi aktiviranja prisustva čestica. Podhlađivanje se obezbeđuje udelom legirajućih elemenata u rastopu. Dodaci rafinatora zrna dovode do viška rastvorenog titana, koji bi trebalo da obezbedi najveće podhlađivanje svih elemenata [39]. Štaviše, tvrdi se da nukleacija napred pomenutih čestica zahteva manje podhlađenje nego druge čestice [40].

Do sada, međutim, nije jasno koliko je rafinatora zrna potrebno za rafinaciju mikrostrukture metala šava-zavisi od legure i uslova zavarivanja. Štaviše, literatura obezbeđuje samo nekoliko i to nekonzistentnih informacija o odnosu veličine zrna metala šava i mehaničkih osobina, posebno žilavosti. Raspoloživi podaci se samo fokusiraju na zavarivanje topljenjem, taložno ojačanih Al legura 2xxx i 7xxx. Zbog toga se ova studija fokusira na rafinaciju zrna TIG metala šava preko dodataka rafinatora zrna kod jedne od najčešće korišćenih Al-Mg legura (Legura 5083) i - radi poređenja komercijalno čistog Al (Legura 1050A). Ispitivan je uticaj na veličinu zrna obe legure koje se upoređuju, kao i uticaj veličine zrna metala šava na tvrdoću, napon tečenja, zateznu čvrstoću, duktilnost i žilavost.

\section{Eksperiment}

\subsection{Materijali i uslovi zavarivanja}

Obrađeni osnovni materijali korišćeni u ovoj studiji su: legura 5083 (Al Mg4,5Mn0,7, stanje H111) koja se često koristi u brodogradnji ili kao materijal posuda i komercijalno čisti aluminijum legura 1050A (Al 99,5, stanje H14). Obe legure su isporučene u obliku limova (debljina $3 \mathrm{~mm}$ ), gde je stepen deformacionog ojačavanja srednji za leguru 1050A ( $1 / 2$ tvrd) i mali za leguru 5083 (manje od $1 / 8$ tvrd). Kao komercijalni rafinator zrna korišćen je Al $\mathrm{Ti}_{i 5} \mathrm{~B}_{1} \mathrm{i}$ isporučen je kao šipka (prečnik $9.5 \mathrm{~mm}$ ). Hemijski sastav svih legura merenih Optičkim Emisionim Spektrometrom (ICP-OES) dat je u tabeli 1. U cilju variranja sadržaja elemenata rafinatora zrna $\mathrm{Ti}$ i $\mathrm{B} \mathrm{u}$ metalu šava, ingoti su liveni tako da sadrže odgovarajući osnovni materijal plus dodaci $\mathrm{Al} \mathrm{Ti}_{5} \mathrm{~B}_{1}$. Svaki liveni ingot je potom mašinski obrađen na nekoliko malih umetaka $(140 \mathrm{~mm} \times 2$ $\mathrm{mm} \times 1.5 \mathrm{~mm}$ ). Žljeb je izbušen na donjoj površini (u pravcu valjanja) kupona za zavarivanje $(140 \mathrm{~mm}$ x $60 \mathrm{~mm}$ x $3 \mathrm{~mm}$ ) koji su izrađeni iz limova osnovnog materijala. Posle toga, i umeci i kuponi su očišćeni odmašćivanjem i nagrizanjem u trajanju od 15 minuta reagensom koji se sastoji od $869 \mathrm{ml}$ $\mathrm{H}_{2} \mathrm{O}, 125 \mathrm{ml} 65 \% \mathrm{HNO}_{3}$ i $6,25 \mathrm{ml} \mathrm{48 \%} \mathrm{HF}$. Svaki umetak je postavljen u žljeb kupona i fiksiran udarcima čekićem. Tada je kupon za zavarivanje pričvršćen u držaču sa livenim umetkom sa donje strane. Deponovani liveni umetak je potpuno istopljen $u$ jednom prolazu, TIG zavareni spoj sa potpunim provarom i parametrima pobrojanim $u$ tabeli 2. Podloška je napravljena od bakra i korišćena je za izbegavanje nepoželjnih prokapina u korenu. U cilju obezbeđenja sličnih veličina zavara u šavu i stepena mešanja umetka, jačina struje je malo veća nego pri zavarivanju legure $1050 \mathrm{~A}$ zbog veće termičke provodljivosti u poređenju sa legurom 5083 [41]. Više detalja o livenju i postupku zavarivanja dati su u [34]. 


\begin{tabular}{|l|c|c|c|c|c|c|c|c|c|c|c|c|c|}
\hline \multirow{2}{*}{ Al loy } & \multicolumn{10}{|c|}{ Chemical composition in wt.-\% } \\
\cline { 2 - 14 } & $\mathrm{Si}$ & $\mathrm{Fe}$ & $\mathrm{Cu}$ & $\mathbf{M n}$ & $\mathbf{M g}$ & $\mathrm{Cr}$ & $\mathbf{N i}$ & $\mathbf{Z n}$ & $\mathrm{Ti}$ & $\mathrm{B}$ & $\mathrm{V}$ & $\mathrm{Zr}$ & $\mathbf{A l}$ \\
\hline $\begin{array}{l}\text { 1050A H14 } \\
\text { (Al 99.5) }\end{array}$ & 0.09 & 0.24 & 0.01 & 0.004 & 0.001 & 0.001 & 0.004 & 0.01 & 0.008 & 0.0003 & 0.01 & 0.001 & Bal. \\
\hline $\begin{array}{l}5083 \text { H111 } \\
\text { (Al Mg4.5Mn0.7) }\end{array}$ & 0.25 & 0.40 & 0.74 & 0.58 & 4.57 & 0.09 & 0.01 & 0.07 & 0.027 & 0.002 & 0.006 & 0.002 & Bal. \\
\hline Al Ti5B1 & 0.06 & 0.11 & - & - & - & - & - & - & 4.98 & 0.99 & 0.02 & - & Bal. \\
\hline
\end{tabular}

Tabela 1: Hemijski sastav osnovnog materijala i rafinatora zrna izmeren optičkim emisionim spektrometrom (ICP-OES).

\begin{tabular}{|l|l|c|}
\hline Parameter & \multicolumn{1}{|c|}{$\begin{array}{c}\text { 1050A } \\
\text { (Al 99.5) }\end{array}$} & \multicolumn{1}{|c|}{$\begin{array}{c}5083 \\
\text { (Al Mg4.5Mn 0.7) }\end{array}$} \\
\hline Current in $\mathrm{A}$ & \multicolumn{1}{|c|}{180} & 175 \\
\hline Voltage in $\mathrm{V}$ & \multicolumn{1}{|c|}{$11.3 \pm 0.2$} \\
\hline Polarity & $\mathrm{AC}(80 \%$ negative, 20\% positive) \\
\hline Frequency & $50 \mathrm{~Hz}$ \\
\hline Torch speed in $\mathrm{mm} \mathrm{s}^{-1}$ & 4.2 \\
\hline Electrode & $\mathrm{W}+2 \% \mathrm{CeO}_{2}$ diameter $3.2 \mathrm{~mm}_{\text {, point angle } 30^{\circ}}$ \\
\hline Shielding gas & $50 \% \mathrm{Ar}_{1} 50 \% \mathrm{He}$ \\
\hline Flow rate & $261 \mathrm{~min}^{-1}$ \\
\hline Distance electrode - coupon & $3 \mathrm{~mm}$ \\
\hline
\end{tabular}

Tabela 2: Parametri TIG zavarivanja korišćeni za stapanje livenih umetaka u osnovni material (current-jačina struje; voltage-napon; polarity-polaritet; frequency-frekvenca; torch speed- brzina pomeranja pištolja ; electrode-elektroda; shielding gas-zaštitni gas; flow rate-brzina protoka; distanceelctrode-coupon-rastojanje elektroda-kupon)

\subsection{Metalografska, hemijska i SEM ispitivanja}

Metalografski uzorci su pripremjeni iz sredine svakog šava da bi se dobio poprečni presek metala šava. Svaki uzorak je brušen, poliran mehanički i anodno nagrižen rastvorom koji sadrži $2 \% \mathrm{HBF}_{4}$ i $98 \% \mathrm{H}_{2} \mathrm{O}$. Mikrografi su napravljeni na mikroskopu korišćenjem polarizovanog svetla koje pomaže kod diferencijacije zrna. Merenje veličine zrna je sprovedeno u najmanje četiri različita položaja svakog poprečnog preseka metala šava procedurom kružnog preseka prema standardu [42] a srednja vrednost za svaki metal šava je izračunata. Hemijski sastav (posebno sadržaj Ti i B) komada koji su isečeni iz zavarenih spojeva određen je pomoću ICP-OES. Neke epruvete iz ispitivanja cepanjem (videti deo 2.3) analizirane su pomoću SEM (Skenirajući Elektronski Mikroskop) u cilju ispitivanja njihove površine preloma. Za ispitivanje hemijskog sastava intermetalnih faza nekih metalografskih uzoraka korišćena je spektroskopija disperzije talasne dužine $\mathrm{X}$ zraka (WDS).

\subsection{Mehanička ispitivanja}

Tvrdoća nekih metalografskih uzoraka merena je metodom Vickers-a uz korišćenje ispitnog opterećenja od 0.3 kiloponda $(=3 \mathrm{~N})$ za leguru $1050 \mathrm{~A}$ i 0.5 kiloponda $(5 \mathrm{~N}$ ) za leguru 5083 da bi se omogućila slična veličina otisaka za obe legure. Takođe, glatke pljosnate epruvete za ispitivanje zatezanjem i epruvete sa zarezom za ispitivanje cepanjem [43] izrađene su iz zavarenih kupona, videti sliku 1. U sredini ovih epruveta za ispitivanje poprečno na šav, debljina lima je smanjena glodanjem sa 3 na $2 \mathrm{~mm}$ sa širinom od $50 \mathrm{~mm}$ (epruveta za zatezanje) ili $18 \mathrm{~mm}$ (epruveta za cepanje) da bi se minimizirao uticaj površine šava na rezultate ispitivanja. Stvarni radijus oštrog korenog zareza $(0,1 \mathrm{~mm})$ i rastojanje između korenog zareza i zadnje strane svih epruveta za ispitivanje cepanjem, izmerene su pre ispitivanja. Posle toga su epruvete podvrgnute opterećenju (zajedno sa epruvetama izrađenim iz osnovnih materijala) kvazistatičkom zatezanju i ispitivanju cepanjem. Brzina kretanja glave je $3 \mathrm{~mm} / \mathrm{min}$ (ispitivanje zatezanjem) ili $2 \mathrm{~mm} / \mathrm{min}$ (ispitivanje cepanjem) i pravac opterećenja je upravan na pravac valjanja epruveta. Optički 3D merni sistem Aramis $^{\mathrm{TM}}$ je služio za merenje deformacije na gornjoj površini epruveta za zatezanje, a potom je izračunavano odgovarajuće istezanje. Posle toga je konstruisana referentna kriva napon-izduženje za izduženje u pravcu opterećenja za metal šava svake epruvete, izračunavanjem srednje vrednosti izduženja iz mnogo lokalnih mernih tačaka na površini metala šava. Zatezni napon je izračunat deljenjem zateznog opterećenja sa početnim poprečnim presekom $\left(50 \mathrm{~mm}^{2}\right)$ epruveta. Konačno, referentna kriva napon-izduženje je konstruisana tako da predstavlja metal šava svake epruvete za 
zatezanje. Iz ovih krivih određeni su čvrstoća otpornosti (Rp0,2), zatezna čvrstoća $(R m)$, plastično širenje pri maksimalnoj sili (Ag) i izduženje posle loma (A). Kod nekih epruveta za ispitivanje zatezanjem, za merenje deformacije korišćen je klipni merač (merna dužina $25 \mathrm{~mm}$ ) u cilju upoređenja ove metode sa optičkim Aramis ${ }^{\mathrm{TM}}$ sistemom.

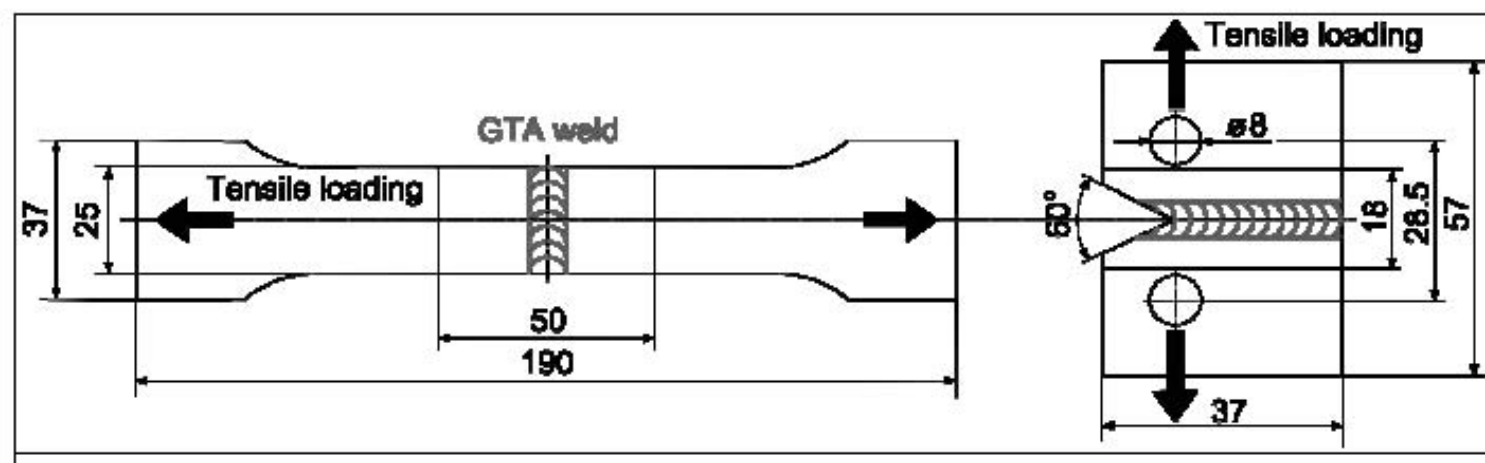

Slika 1.epruvete za ispitivanje (a) zatezanjem i (b) cepanjem

(GTA weld-TIG šav;Tensile loading-zatezno opterećenje)

Procedura ispitivanja cepanjem u ovoj studiji ([43]) je poznata kao odgovarajući indikator za žilavost tankih Al limova [44]. Iz ovog razloga, takvo ispitivanje cepanjem se široko primenjuje za određivanje žilavosti zavarenog spoja u avio industriji $[45,46]$ gde se većina delova izrađuje od tankih Al limova (debljina: nekoliko $\mathrm{mm}$ ). U ovoj studiji je vertikalno pomeranje između dve čivije (u pravcu opterećenja) mereno klipnim meračem (merna dužina $28,5 \mathrm{~mm}$, videti sliku 1) koji je postavljen direktno na čivije. Sve epruvete su bile opterećene dok se nije proširio lom (ispitivanje zatezanjem) ili dok propagirajuća prslina nije potpuno podelila epruvetu na dva dela (ispitivanje cepanjem). Posle toga je konstruisana kriva silapomeranje za svaku epruvetu prema odgovarajućem standardu [43], videti sliku 2. Iz ovih dijagrama je izračunata energija potrebna za nastanak (UIE) i za širenje (UPE) prsline (kroz integrisanje) površine ispod krive sila-pomeranje:

$$
\begin{aligned}
& U I E=\frac{I}{w \cdot t} \int_{s=0}^{s=s_{i}} F \cdot d s \\
& U P E=\frac{I}{w \cdot t} \int_{s=s_{i}}^{s=13 f \pi r z} F \cdot d s
\end{aligned}
$$

gde je $w$ širina epruvete $(25 \mathrm{~mm}$, rastojanje između korena zareza i donje strane epruvete), $t$ je debljina epruvete $(2 \mathrm{~mm}), \quad F$ je sila zatezanja, $s$ je pomeranje u pravcu opterećenja i si je pomeranje pri nastajanju prsline. Gornja granica integrala za izračunavanje UPE izabrana je na rastojanju od 13 $\mathrm{mm}$. Treba naglasiti da se prema standardu [43] smatra da prslina nastaje u momentu dostizanja maksimalne sile (Fmax), videti sliku 2. U ovoj studiji je, međutim zapaženo da prsline ne nastaju uvek pri maksimalnoj sili, već često posle postizanja Fmax (posebno kod legure 1050A). Iz ovog razloga, si je određen optičkim 3D mernim sistemom (Aramis ${ }^{\mathrm{TM}}$ ) i UIE $i$ UPE su izračunate sa stvarnim vrednostima si.

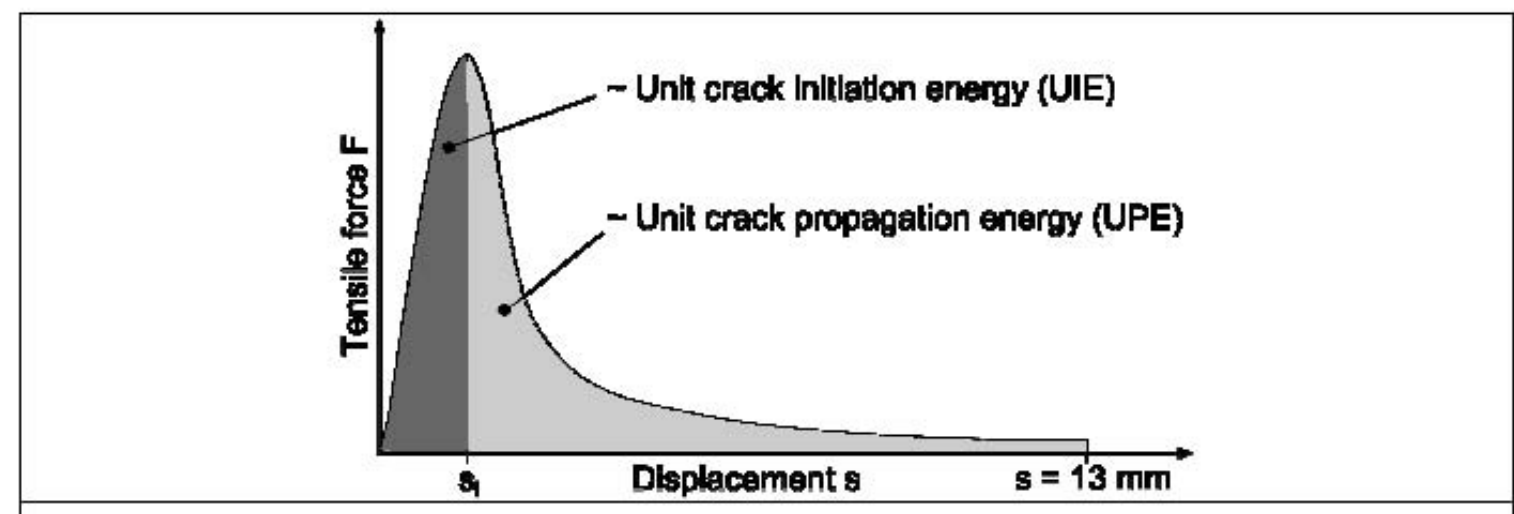

Slika 2. Jedinice energije za nastanak i širenje prsline zavisno od sile zatezanja i pomeranja pri ispitivanju

\section{Rezultati i diskusija} cepanjem

\subsection{Uticaj veličine zrna}

Sadržaj Ti/B u metalu šava može da varira preko kontrolisanog dodatka rafinatora zrna $\mathrm{Al} \mathrm{Ti}_{5} \mathrm{~B}_{1} \mathrm{u}$ livene umetke. Rezultujuća srednja vrednost

veličine zrna u metalu šava je značajno smanjena, gde maksimalna veličina zrna opada 44\% (Legura 5083) do 86\% (Legura 1050A), videti sliku 3, kada 
sadržaj $\mathrm{Ti}$ u metalu šava reprezentuje dodatke rafinatora zrna. Svaka pogrešna oznaka na slici 3 je standardno odstupanje različitih srednjih vrednosti veličina zrna koje su određene u (najmanje četiri) različita preseka za svaki metal šava. Dodaci rafinatora zrna dovode do promene oblika zrna od stubičastog do istoosnog. Efekat rafinacije zrna preko kalemljenja je opisan na više mesta [22, 28, 47, 48] za metal šava od aluminijuma; to se može objasniti 1) većim brojem aktivnih očvrslih nukleusa kao što su $\mathrm{TiB}_{2}$ [36] i $\mathrm{Al}_{3} \mathrm{Ti}$ [37] koji su prisutni u zavarivačkoj kupki tokom očvršćavanja i 2) većim stepenom podhlađenja usled sastava, koje je posebno obezbeđeno rastvorenim titanom [38]. Čak i mali nivoi dodataka $\mathrm{Al} \mathrm{Ti}_{5} \mathrm{~B}_{1}$ (što dovodi do sadržaja $\mathrm{Ti}<0,05$ tež.-\%) rezultuju u velikom smanjenju veličine zrna, što je više izraženo kod komercijalno čistog Al (Legura 1050A) nego kod legure 5083.

Razlozi za veći efekat rafinacije kod legure 1050A su verovatno [49]:

- Sadržaj rastvorenih elemenata: kada nisu dodati rafinatori (levi ugao na slici 3 ), komercijalno čisti Al (legura 1050A) obezbeđuje vrlo sporo podhlađivanje, što rezultuje $u$ manje aktivnim nukleusima pri očvršćavanju i zato je veća veličina zrna u poređenju sa legurom 5083.

- Interakcije $\mathrm{TiB}_{2}$ i/ili $\mathrm{Al}_{3} \mathrm{Ti}$ sa legirajućim elementima u osnovnom materijalu redukuju efikasnost rafinatora zrna i zato su poželjniji kod legure 5083 nego kod legure 1050A $[50,51]$.

- Termička provodljivost je veća kod legure $1050 \mathrm{~A}(210 \mathrm{~W} / \mathrm{m} \square \mathrm{K})$ nego kod legure $5083(110 \mathrm{~W} / \mathrm{m} \square \mathrm{K})$ [41] što dovodi do $30 \%$ veće

brzine hlađenja u zavarenim spojevima od 1050A [49], što povratno povećava podhlađivanje i smanjenje veličine zrna [40].

Veličina zrna u metalu šava zasićenom određenim nivoom rafinatora zrna, može se videti na slici 3 . Ova minimalna veličina zrna je moguća zbog čestica $\mathrm{Al}_{3} \mathrm{Ti}$ koje nastaju iz rafinatora zrna $\mathrm{Ti}_{5} \mathrm{~B}_{1} \mathrm{i}$ iz velikih aglomerata $\mathrm{Al}_{3} \mathrm{Ti}$ vezanih za Ti [49]. Sledeći razlog može biti privremeni rast temeperature, usled latentne toplote koja se oslobađa preko rasta Al kristala koji umanjuju podhlađivanje i time veličinu zrna u livenoj strukturi [52].

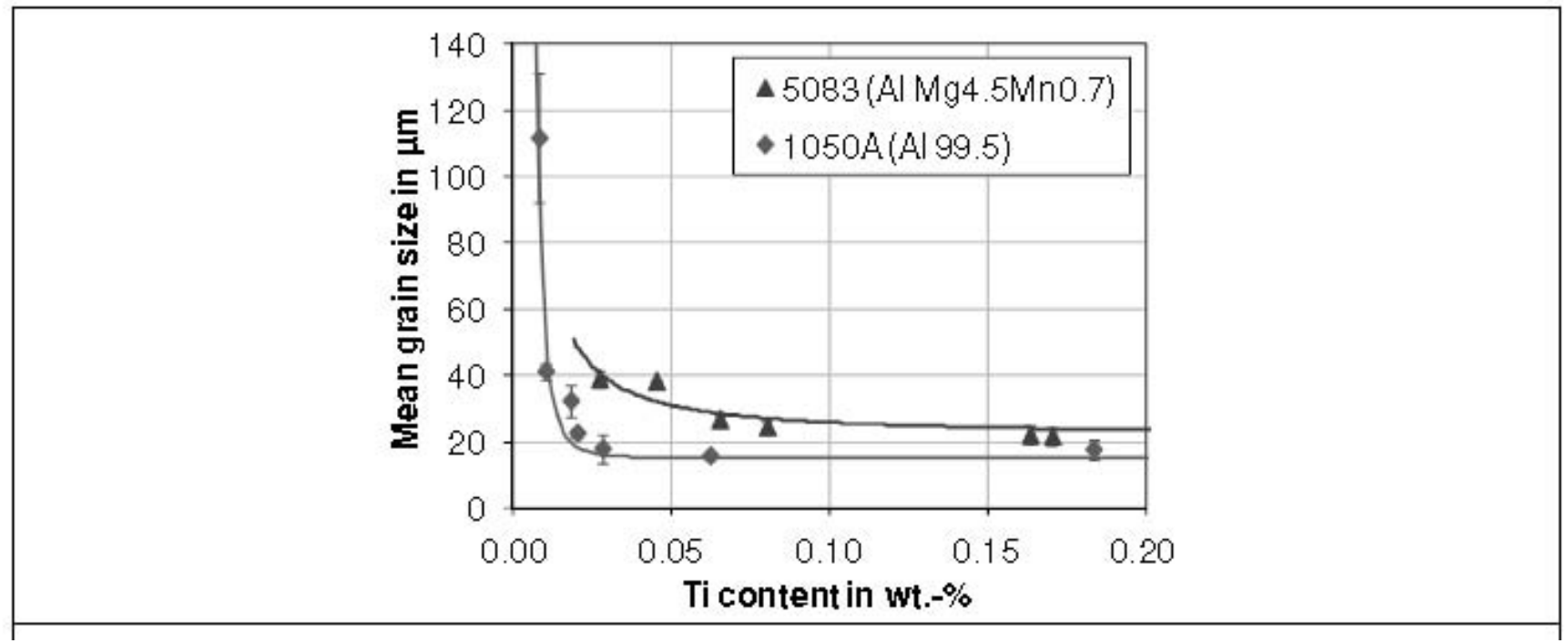

Slika 3. Srednja vrednost veličine zrna zavisno od sadržaja Ti u metalu šava, izmereno ICP-OES. TIG zavarivanje, debljina lima 3 $\mathrm{mm}$, brzina kretanja pištolja $4,2 \mathrm{~mm} / \mathrm{s}$, srednja vrednost količine unete toplote $482 \mathrm{~J} / \mathrm{mm}$

Merenja veličine zrna i srednje vrednosti veličina materijalu $(20 \mu \mathrm{m})$ i $\operatorname{HAZ}(31 \mu \mathrm{m})$ kada zrna u zoni uticaja toplote (HAZ) i osnovnom materijalu prikazana za finozrne zavarene spojeve od 1050A, govore da je veličina zrna u metalu šava $(16 \mu \mathrm{m})$ čak manja nego u osnovnom rekristalizacija dovodi do povećanja veličine zrna, videti tabelu 3. To nije bio slučaj kod zavarenih spojeva od legure 5083, gde je srednja vrednost veličine zrna osnovnog materijala i HAZ bila ista.

\begin{tabular}{|l|c|c|c|c|c|c|c|c|c|}
\hline \multirow{2}{*}{ Parameter } & \multicolumn{3}{|c|}{ 1050A (Al 99.5) } & \multicolumn{4}{c|}{ 5083 (AI Mg4.5Mn0.7) } \\
\cline { 2 - 10 } & BM & HAZ & \multicolumn{2}{|c|}{ WM } & BM & HAZ & \multicolumn{3}{c|}{ WM } \\
\hline Ti content in wt. $\%$ & 0.01 & 0.01 & 0.01 & 0.10 & 0.03 & 0.03 & 0.03 & 0.07 & 0.17 \\
\hline Mean grain size in $\mu \mathrm{m}$ & 20 & 31 & 112 & 16 & 14 & 14 & 39 & 28 & 22 \\
\hline
\end{tabular}

Tabela 3: Srednja vrednost veličine zrna osnovnog materijala (BM), zone uticaja toplote (HAZ) i metala šava (WM) zavisno od sadržaja Ti 
Rafinacija zrna u metalu šava od aluminijuma može da smanji osetljivost metala šava na solidifikacione prsline i time poboljša zavarljivost [26, 28]. Ovo je prikazano u prethodnoj studiji, gde je nastanak solidifikacionih prslina po centralnoj liniji u TIG zavarenim spojevima kod legure 6082 (Al Si1MgMn), osetljive na solidifikacione prsline, sprečen rafinacijom zrna [29]. Zbog odlične zavarljivosti legura 1050A i 5083, ova studija se fokusira na uticaj veličine zrna u metalu šava na mehaničke ososbine.

\subsection{Tvrdoća}

Na slici 4a prikazan je profil tvrdoća po Vickersu tipičnog zavarenog spoja legure 1050A (sa srednjom vrednosti veličine zrna metala šava od 18 $\mu \mathrm{m})$ i za leguru $5083(39 \mu \mathrm{m})$. Pogrešne oznake indikuju standardno odstupanje pojedinačnih merenja tvrdoće u metalu šava i HAZ svake legure.
Kao što se i očekivalo, tvrdoća zavarenih spojeva od legure 1050A je mnogo manja nego kod zavarenih spojeva od legure 5083. Tvrdoća osnovnog materijala je određena kao HV 59 (Legura 1050A) i HV 84 (Legura 5083) i tvrdoća metala šava i HAZ su određene kao slične za svaku leguru. Zbog toga, prema tabeli 3, različita veličina zrna HAZ (31 $\mu \mathrm{m}$, poziv na tabelu 3$)$ i metal šava (18 $\mu \mathrm{m}$, videti sliku $4 a)$ za zavarene spojeve od legure 1050A nije loše uticala na odgovarajuće tvrdoće. Slika $4 \mathrm{~b}$ potvrđuje da srednja vrednost veličine zrna u metalu šava nema značajan uticaj na srednju vrednost tvrdoće metala šava - nasuprot velikoj razlici u odgovarajućim veličinama zrna, pozivanje na sliku 3. Prethodna studija je utvrdila malo povećanje tvrdoće sa smanjenjem veličine zrna kod TIG metala šava taložno ojačanih Al legura 7020 [21].

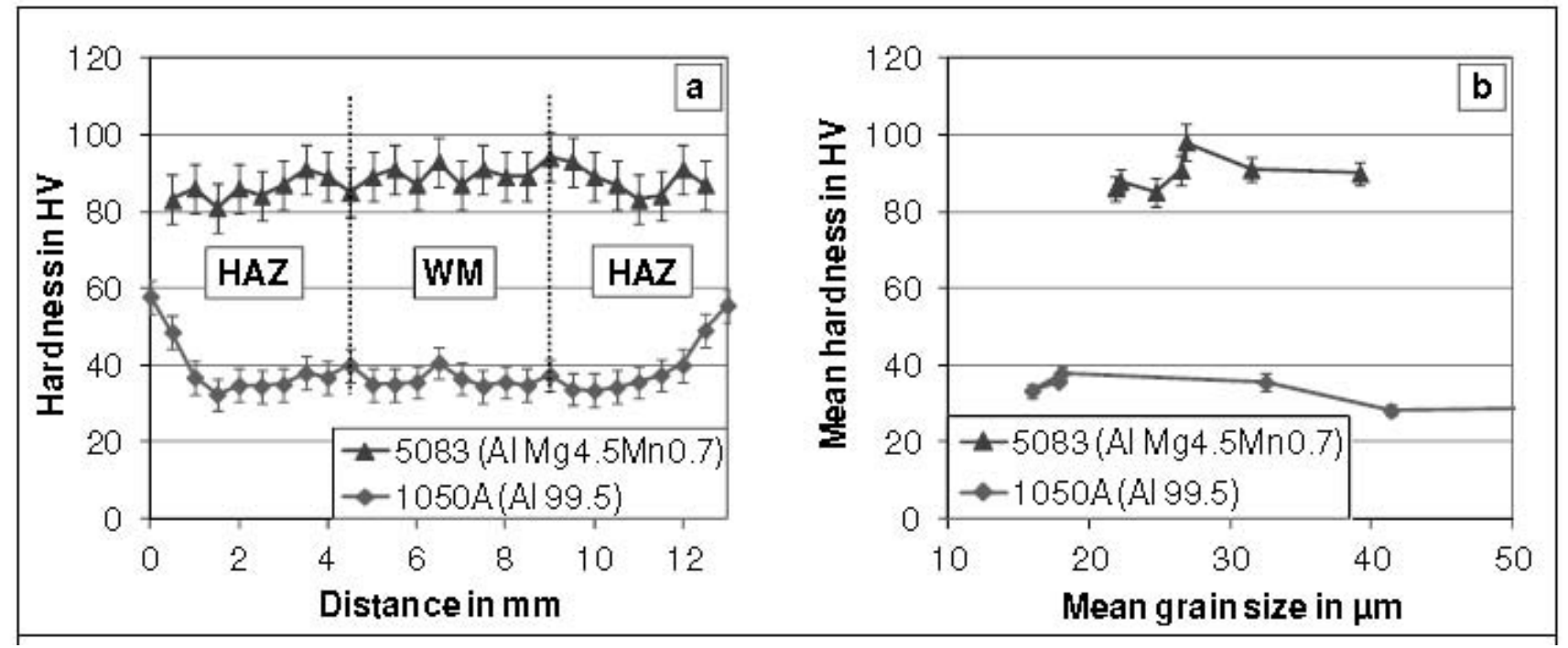

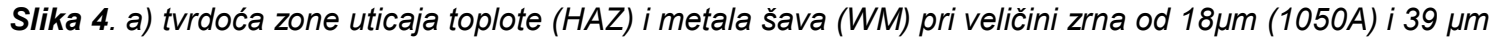

(5083) $i$ b) srednja vrednost tvrdoće metala šava zavisno od srednje vrednosti veličine zrna. TIG zavarivanje,

debljina lima $3 \mathrm{~mm}$, brzina kretanja pištolja $4,2 \mathrm{~mm} / \mathrm{s}$, srednja vrednost količine unete toplote $482 \mathrm{~J} / \mathrm{mm}$

Mora se napomenuti da opterećenje pri ispitivanju tvrdoće stvara otiske dovoljne veličine (prečnik oko $100 \mu \mathrm{m})$ da bi se dozvolilo poređenje merenja tvrdoće u zavarenim spojevima sa grubom veličinom zrna (srednja vrednost veličine zrna npr. $100 \mu \mathrm{m}$ ) i finom veličinom zrna (srednja vrednost veličine zrna npr. $16 \mu \mathrm{m}$ ).

\section{3 Čvrstoća i duktilnost}

$\mathrm{Na}$ slici 5 prikazani su rezultati ispitivanja zatezanjem za leguru 5083 na epruvetama izrađenim od osnovnog materijala ili zavarenih spojeva različite srednje vrednosti veličine zrna. Svaka vrednost je srednja vrednost 5 različitih ispitivanja zatezanjem. Ustanovljeno je da su parametri čvrstoće, granica otpornosti $(R p 0,2)$ i zatezna čvrstoća $(R m)$ osnovnog materijala veći nego kod metala šava, pri čemu veličina zrna ne pokazuje uticaj na parametre čvrstoće, videti sliku 5a. Lom usled zatezanja koji se javlja u epruvetama od osnovnog materijala je uvek u pravcu maksimalnog napona smicanja odnosno u ravni pod $45^{\circ}$ na pravac opterećenja. $U$ zavarenim epruvetama, lom se uvek javlja u metalu šava i ravni pod $90^{\circ}$ na pravac opterećenja. Odgovarajući parametri izduženja, plastičnog širenja pri maksimalnoj sili $(A g)$ i izduženja posle loma $(A)$ prikazani su na slici $5 \mathrm{~b}$. Oba izduženja su mnogo manja u metalu šava nego u osnovnom materijalu, pri čemu smanjenje srednje vrednosti veličine zrna u metalu šava dovodi do značajnog povećanja vrednosti izduženja. Prema tome, rafinacija zrna je izmenila duktilnost metala šava od legure 5083 ali ne i njegovu čvrstoću 


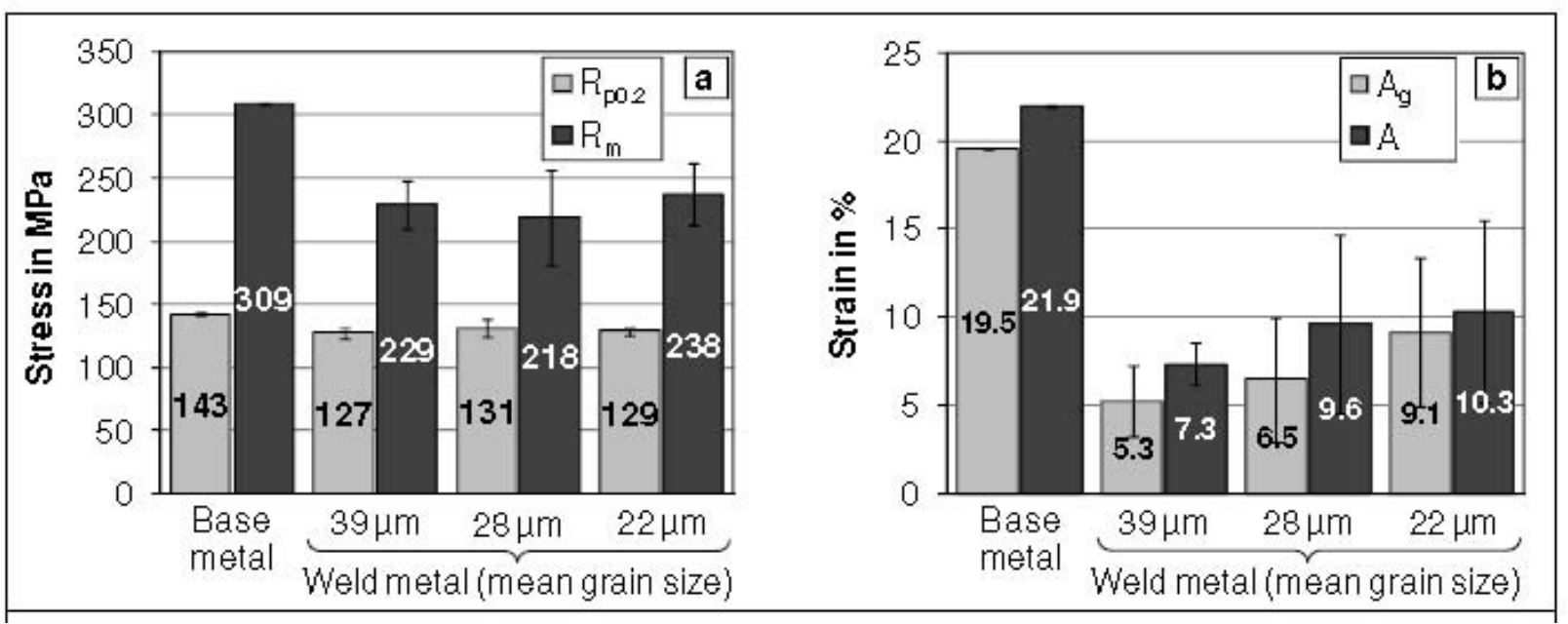

Slika 5. Granica otpornosti Rp0,2 i zatezna čvrstoća Rm (a) i plastično širenje pri maksimalnoj sili Ag i izduženje nakon loma $A$ (b) osnovnog materijala i metala šava pri različitim veličinama zrna kod ispitivanja zatezanjem. TIG zavarivanje, debljina lima $3 \mathrm{~mm}$, brzina kretanja pištolja 4,2 $\mathrm{mm} / \mathrm{s}$, srednja vrednost količine unete toplote $482 \mathrm{~J} / \mathrm{mm}$

Slika 5a podržava mišljenje da je ojačavanje preko veličine zrna uporedivo manje u Al legurama [9-11]. Štaviše, rezultati sa obe slike 5 a i b potvrđuju prethodne studije o TIG zavarenim spojevima sa rafinisanim zrnima koje izveštavaju za 2xxx i 7xxx Al legure da postoji samo mali uticaj veličine zrna na čvrstoću i napon tečenja i izražen efekat deformabilnosti [21-23]. Sledeći razlog za poboljšanje duktilnosti (videti sliku $5 b$ ) može biti sprečavanje dugačkih perjastih zrna koja smo pronašli u grubozrnom ali ne i u finozrnom metalu šava 5083 [34]. Takvi dvojnički kristali se često javljaju u livenim strukturama 5083 [40], kada mogu da oslabe mehaničke osobine [53].

Razlog velikom padu duktilnosti od epruveta iz osnovnog materijala ka zavarenim epruvetama (poziv na sliku 5b) može biti uvećan usled gubitka elemenata tokom zavarivanja: Hemijska analiza metala šava je pokazala da je znatan deo Mg (pribl. 10\%) i Si (pribl. 25\%) izgubljen tokom TIG zavarivanja - verovatno usled isparavanja i nezavisnosnog povećanja sadržaja $\mathrm{Ti}$ ili veličine zrna. Ovo može da smanji deformabilnost metala šava. Pogrešne oznake (posebno na slici $5 b$ ) su verovatno usled nehomogenosti u metalu šava kao što su pore, segregacije i varijacije u lokalnoj veličini zrna (poziv na pogrešne oznake na slici 3) koje se ne mogu izbeći u postupcima zavarivanja topljenjem. Shodno tome, merenje deformacije optičkim Aramis ${ }^{\mathrm{TM}}$ sistemom je potvrdilo da većina epruveta za ispitivanje zatezanjem ima lokalne pikove plastične deformacije u metalu šava. Ove loše tačke imaju malu čvrstoću što rezultuje u eventualno ranom lomu cele epruvete. Takođe, ovo zapažanje je dodatno objašnjenje za pad duktilnosti na slici $5 b$. Pored toga, slika $5 b$ jasno pokazuje pozitivan uticaj rafinacije zrna na duktilnost zavarenih spojeva od legure 5083.

Kod nekih epruveta za zatezanje, obavljena su komparativna merenja deformacije pomoću klipnog merača (merna dužina $25 \mathrm{~mm}$ ). Rezultati su potvrdili vrlo male razlike između obe metode (klipni merač i optički sistem Aramis ${ }^{\mathrm{TM}}$ ); razlike $\mathrm{u}$ izduženju su bile samo do $0,3 \%$, što je ekvivalentno relativnoj grešci od $2 \%$.

Obe metode i klip i Aramis ${ }^{\mathrm{TM}}$ su takođe korišćeni za leguru 1050A pri ispitivanju zatezanjem epruveta iz osnovnog materijala i metala šava. Kao rezultat, srednje vrednosti za osnovni materijal 1050A su bile $108 \mathrm{MPa}(\mathrm{Rp} 0,2), 122 \mathrm{MPa}(\mathrm{Rm})$ i 13\% (A), određene klipnim meračem. Ove vrednosti su u zavisnosti od stepena hladne obrade ( $1 / 2$ tvrd) limova od 1050A. Nasuprot leguri 5083, sve zavarene epruvete za zatezanje od 1050A su se polomile u HAZ $\left(90^{\circ} \mathrm{u}\right.$ odnosu na pravac opterećenja) gde je plastična deformacija bila najveća. Razlog za ovaj način loma je rekristalizacija HAZ tokom zavarivanja (videti deo 3.2) što rezultuje u gubitku efekta obrade na hladno kao i u povećanju veličine zrna (poziv na tabelu 3). Tako je najgori deo zavarenih spojeva od 1050A bio HAZ - čak i merenja tvrdoće (poziv na sliku 4) to nisu jasno indikovala. Posledica toga je da ni parametri čvrstoće, ni parametri izduženja za metal šava od legure 1050A nisu određeni. Rezultati iz ispitivanja zatezanjem su pokazali da je primarni mehanizam ojačavanja u leguri 1050A, ojačavanje preko veličine zrna, dok je kod legure 5083 to ojačavanje preko čvrstog rastvora.

-Kraj 1. dela

NASTAVAK U SLEDEĆEM BROJU 